\title{
Changing Audience Behaviour: Festival Goers and Throwaway Tents
}

\section{Background}

Though the world of outdoor festivals offers the opportunity of enjoyable recreational activity, it hides a potential for environmental damage that is concerning. A number of writers (Cierjacks et al, 2012; Shirley et al, 2001) have pointed to the wide ranging adverse ecological impacts that present long term detrimental effects to the surrounding ecology. This damage to festival sites and surrounding areas ranges across noise pollution, airborne contaminants, degradation of local flora and high levels of waste. For large scale festivals (over 50,000 attendees), the level of waste is a particularly serious problem whether viewed simply as an issue of environmental damage or, pragmatically, as an increase in the charges incurred with landfill. Although substantial efforts have been made by festival managers to manage waste by separation and recycling schemes, the management of waste continues to be seen as a central issue in the achievement of sustainable goals.

Of course, festival managers have attempted a wide range of initiatives in support of their central aim to reduce the waste going to landfill. Yet, according to Cierjacks et al (2012), existing published data is unable to demonstrate the success of specific waste reduction approaches. Additionally, there appears to be little application of waste prevention strategies (Church, 2012, Cierjacks et al, 2012) where the process of changing audience behaviour and attitude towards consumption can help reduce the initial problem (EEA, 2012; Salhofer et al., 2008; Santos et al.,2005; Silva- Cavalcanti et al. (2009)

This general lack of demonstrable success in changing audience behaviour is not surprising as decisions to consume and consumption itself can take place at different points and is influenced by many variables such as the place of consumption and site design. A view supported by the findings of Cierjacks et al (2012) who identify littering and residual waste per person is higher in food, sanitation, and camping zones. However, this is not due simply to spatial aspects of the festival site and, as Silva-Cavalcanti et al. (2009) suggest, littering is influenced not just by the density of attendees and site characteristics but by visitor behaviour.

Adding to this, attendees make choices about travel, eating, drinking and, possibly, accommodation that are separate to the decision to become part of the audience (Jones et al., 2006). In doing so, the audience bring with them their own attitudes towards 
sustainability which festival management need to consider and, subsequently, according to various writers (Haq et al., 2008; Frame and Newton, 2007; McKenzie-Mohr, 2000), will find the conduit that influences consumption behaviour is social marketing.

Turning specifically to the problem of throwaway tents, Jon Allen (2010) of The Green Tent Company spells out the behavioural problem well. He suggested that $17 \%$ of UK festival waste going to landfill results from abandoned tents. This situation being exacerbated by the growth in the live music market estimated at $£ 1,681$ million by 2017 , a $9.1 \%$ increase over the expected total for 2012 (Mintel, 2012).

Whilst these figures are estimated, the problem is obvious (Smithers and Ladmore, 2011), yet, there has been little developed in terms of management frameworks that can offer guidance to festival or other event management on the prevention of waste via changing audience behaviour. Most of the research to date has offered a broad exploration of social marketing interventions at events as a means to promote pro-sustainable behaviour (Mair and Laing, 2013). In this paper, it is intended to use the example of 'throwaway' tents in a way that will build a conceptual framework for strategic decision making to address behavioural change and achieve sustainable objectives at festivals.

\section{Methodology}

The intention of this conceptual paper is to utilise the literature of social marketing and consumer behaviour to develop a decision path that acts as a framework to assist festival managers in determining appropriate initiatives to change audience behaviour in a sustainable direction. To justify such a conceptual framework, an analysis of literature is completed paying particular attention to social marketing and determinants of behaviour focusing upon where and when behaviour takes place within a festival context.

An informal application of the framework across a small sample of festivals is performed in order to determine its applicability in terms of both relevance and potential for further work. Later, a full web content analysis within this paper will take on a traditionalist approach expressed by McMillian (2000) in Herring (2010), where the research formulates a research question; a sample is selected (in this case, considering festivals in the UK that have attendance in excess of 50,000 people in 2012 in order to see the problem at its worst); categories are defined to enable coding; singular coders are used, trained and reliability checked; resulting data is analysed and interpreted. This will allow for rigor and standardisation across comparative social marketing and behavioural change studies where content analysis has been used as a primary method. 
In narrowing down the traditionalist approach to web content analysis it was decided that textual dialogue (or polylogue) such as blogs, forums and chat rooms did not offer a representation of management practices and reflected a netnographic method that focused upon the language used within the website. The authors are more interested in the hypertextual social marketing interventions described on websites (including when and how these social marketing interventions are communicated to the audience) and their relationship to literature noted above.

\section{Literature}

\section{(a) Social Marketing: Enhancing Waste Management}

Many of us are used to the simple mantras of waste management such as 'reduce, reuse and recycle' and the many coloured waste bins provided by local councils for refuse collection. However, changing consumption behaviour in a direction that supports sustainable development requires us to influence complex activities affected by a wide variety of factors. Whilst governments may choose to influence behaviour via a legal framework, the literature suggests that social marketing is a key tool for influencing behaviour and, hence, offers a key to unlock sustainable choices amongst festival audiences (Frame and Newton, 2007). Other writers have also noted that social marketing intervention programmes feature strongly when influencing behaviour in a sustainable direction (Haq et al., 2008).

Peattie and Peattie (2009) define social marketing as utilising tools, techniques and concepts derived from commercial marketing in pursuit of social goals. Kotler and Lee (2008) propose that this marketing technique intends to influence a target audience to voluntarily accept, reject, modify, or abandon their behaviour for the benefits of individuals, groups or society. In this way, social marketing supersedes simple social communications such as 'stop smoking' signs and adds social science ideas into those of marketing (Kurani \& Turrentine, 2002). It follows that social marketing finds many of the concepts of commercial marketing to be useful in developing initiatives. These often resemble their commercial marketing strategy counterparts in their use of social marketing mixes designed to influence a target consumer.

Some suggest that these social marketing initiatives aimed at environmental concerns simply appease a socially minded public without achieving their desired effect (Peattie and Crane, 2005; Rex and Baumann, 2007 in Frame and Newton, 2007). Their main criticism being that the environment surrounding the consumer is much more influential than a simple 
'green marketing' approach such as an eco-label. Here, the intention is not to debate this view as it depends on the specific initiative and its relative success. Indeed, failures may well support the proposition found herein that there are few frameworks to help those using social marketing.

One might argue that the identification of the ethical consumer (Shaw et al, 2005) is a further restriction on the application of social marketing techniques as it implies that only this segment of the target is likely to respond to social marketing initiatives. Additionally, the target consumer at an event self selects by deciding that the event is of interest to them which means that there may or may not be ethical consumers amongst this group. However, herein, it is proposed that the importance of this factor depends on the value that the consumer perceives may be gained (or lost) by adopting the preferred behaviour. In essence, any framework to develop social marketing initiatives needs to reflect the consumer target, the preferred behaviour(s) and the value perceived in its adoption. For example, returning to the throwaway tent, the behaviours options maybe considered as those typical of potential waste materials i.e. reduce to a smaller tent, re-use the tent later, recycle if possible. To this, marketing would suggest the additional option of substitution where the same benefit (accommodation) is achieved by replacing with another choice such as a camper van or hotel. Later, the way in which consumers might perceive value in each of these behaviours will be addressed.

Beyond the theories that reflect commercial marketing, Andreasen (2006) has highlighted the importance of upstream influences from advocates for behaviour change as well as the downstream social marketing initiatives. Other frameworks have attempted to place social marketing in the context of various marketing philosophies. Gordon (2011) proposes the concept of sustainable marketing which combines green marketing (developing and marketing more sustainable products and services developed within sustainable processes), social marketing (using upstream and downstream marketing to influence behaviour) and critical marketing (analysing marketing using a critical approach that, say, might challenge consumption as a prerequisite). In a broader context, Rothschild (1999) draws our attention to the consumer reaction in the face of legal frameworks and marketing. Herein, the concentration is on social marketing that affects downstream activity to produce a sustainable service, the event, whilst recognising the impact of upstream social marketing and commercial paradigms such as the need for consumption in healthy markets. The emphasis reflects the framework used by Kotler and Lee (2008) where the development of social marketing mixes is based on traditional elements including situational analysis, defined target markets and so on. 
In commercial marketing, consumer behaviour tends to be seen as purchasing behaviour; defined by Kotler et al. (2008) as the recognition of a need, searching information that may help satisfy that need, evaluation of the options, purchase and post-purchase evaluation. Whilst the latter element assumes consumption, it is noticeable that this is absent from the process itself and marketing influences at this stage seems to be neglected. However, in the application of social marketing to an event, one might wish to persuade attendees to consume in a sustainable manner. So, immediately, the expanded process highlights that achieving sustainable goals requires corporations to influence consumer behaviour in not only the purchasing choice but the consumption too (Henderson, 2011).

Engaging in sustainable consumption can, according to Tonglet et al. (2004) include the influences of moral norms, past experience, situational factors and the recognition of the consequences of recycling. These psychological antecedents can be traced back to Social Cognitive Theory (SCT) which Stone (2008) defines as human behaviour based on a series of triadic reciprocal interactions between personal factors, behaviour, and the environment (Lin, 2010, Bandura, 2002). Casual observation of consumer behaviour texts such as Solomon et al (2010) reveals that marketing has absorbed cognitive thinking ideas into its understanding of basic purchasing processes. Furthermore, it can be argued that social marketing encourages the consumer to 'buy into' the benefits of a particular behaviour.

According to the ideas of SCT, behaviour is determined by 5 key components that, beyond the environmental determinants of behaviour, emphasise the personal factors to include psychological determinants of behaviour, observational learning, self-regulation and moral disengagement. Linked to these ideas, Amaya and Petosa, (2011) have more recently proposed self-efficacy linked to self-regulation as central to this blend of outcome expectations, beliefs, self-perceptions, and intentions. Accordingly, this central construct indicates behaviour is motivated by self-monitoring; goal-setting; feedback; self-reward; selfinstruction; and social support. All of which are couched in the process led motivation of Vroom's expectancy theory (Mullins, 2007) where consumers place value on outcomes.

Returning to environmental determinants of behaviour, these are categorised as external and physical elements such as extrinsic motivational (rewards or punishment) tools, resources, and environmental changes that help facilitate change by making new behaviours easier to perform (O'Conner, et al., 2002). Then, there is observational learning derived from Social Learning Theory (Cramp and Brawley, 2006) that highlights how learning occurs by watching others within our nuclear and extended social groups. 
So, for example, a festival goer may learn that financial reward may be gained by returning drinks glasses that were sold with a deposit and this behaviour may have been learnt by observing others adopting this behaviour. Sadly, a festival goer may also choose to throw waste on the ground knowing that someone has to collect this. This moral disengagement reflects the personal standards within an individual and scopes the behaviour between moral engagement and disengagement (Bandura, 2002). According to Fiske (2004), this moral disengagement occurs in the process of convincing the self that ethical standards do not apply to particular context and the separation of moral reactions from inhumane conduct.

Such disengagement suggests the consumer makes a careful, deliberate consideration of outcomes within the decision process. Yet, marketing theory suggests this is further complicated by the fact that the consumer may have a low or high involvement with the process (Zaichkowsky,1986). If the travel to the festival is expensive, for example, the consumer is more likely to have a high level of involvement in the decision process. Here, it could be argued that there ought to be a greater opportunity to engage them in the consideration of sustainable event choices e.g. to travel in a sustainable manner. On the other hand, one could consider that simple behaviour choices of low cost, perhaps to drop waste on the ground, offer much less in terms of engaging the consumer in a low involvement process. Rothschild (1979) notes the difficulties this implies for those producing marketing communication in low involvement situations.

\section{(c) Where Audience Behaviour is Determined}

Whilst the preceding section guides in the understanding of how individuals decide upon a particular behaviour, it is clear that these choices are shaped at different places and points in time. Hence, for example, the importance of advocates in upstream social marketing (Andreasen, 2006) where an artist can make clear statements about preferred behaviour that can influence their fans' decisions (Henderson, forthcoming). Having recognised this important point, festival management must determine at what places and points in time it can best address behaviour change to affecting the attendees' decisions.

A festival attendee makes use of a number of spatial and temporal variations when making the numerous purchasing or behavioural decisions along the way between choice to attend the event and the return home. For most, decisions about the mode of transport and accommodation are likely to be made well in advance of departure. Whereas decisions about eating and drinking may be made in advance by some, yet, others may decide at the last minute. Some may make these decisions at home, online, away from home, on site at the festival and, indeed, attitudes can be shaped at any place or point in time. 
To capture this sense of place and time, the behaviour setting has been explored in the Behavioural Perspective Model (BPM), (Foxall, 1999). Reflecting the environmental determinants within the earlier discussed SCT, the model highlights the importance of place as a behaviour setting while also pointing to the temporal via the learnt history of the consumer as an equivalent to psychological determinants. Additionally, the model considers the nature of reinforcement which emphasises value to the consumer including rewards that offer benefit as 'added value' and punishments that in a sense are costs or 'removed value'. These reinforcements may be 'utilitarian' and immediately impacting the consumer or 'Informational' by their explanation of the benefits or costs of the proposed behaviour. In essence, offering material satisfaction (utilitarian and functional) or leading to improvement in social status and/or self-esteem (informational and symbolic). These shape the behaviour (as a primary operant condition) based on the different combinations of low or high reinforcement and functional or symbolic consumption.

\section{(d) What Value Links To Audience Behaviour}

Above, it is noted that behaviour is determined by a range of personal motivations which require individuals to make value judgements when they form attitudes and make decisions. So, turning to consumer value typologies is helpful in understanding how particular behaviours are selected based on value. In Table 1, Holbrook (1999) offers a framework for understanding different types of value that might be considered alongside different behaviours.

In making sustainable choices per-se, value could be perceived as other-oriented rather than self-oriented i.e. the consumer is making a choice that offers benefits to 'others'. Of course, these 'others' might include relatives or close friends and it is not uncommon for those proposing sustainable choices to suggest that it is 'for the children'. Similarly, sustainable choices require action on behalf of the consumer i.e. the value is active and not reactive. Hence, the most obvious value types are those of 'Ethics' and 'Status' as active and other oriented considerations of value that represent virtuous behaviour choices. When such a choice is intrinsic i.e. 'Ethics', the individual sees the chosen action as 'doing the right thing'. If on the other hand, 'doing the right thing' might be seen as an action that is taken to impress others, the choice can be seen as extrinsic and offering 'Status'. 


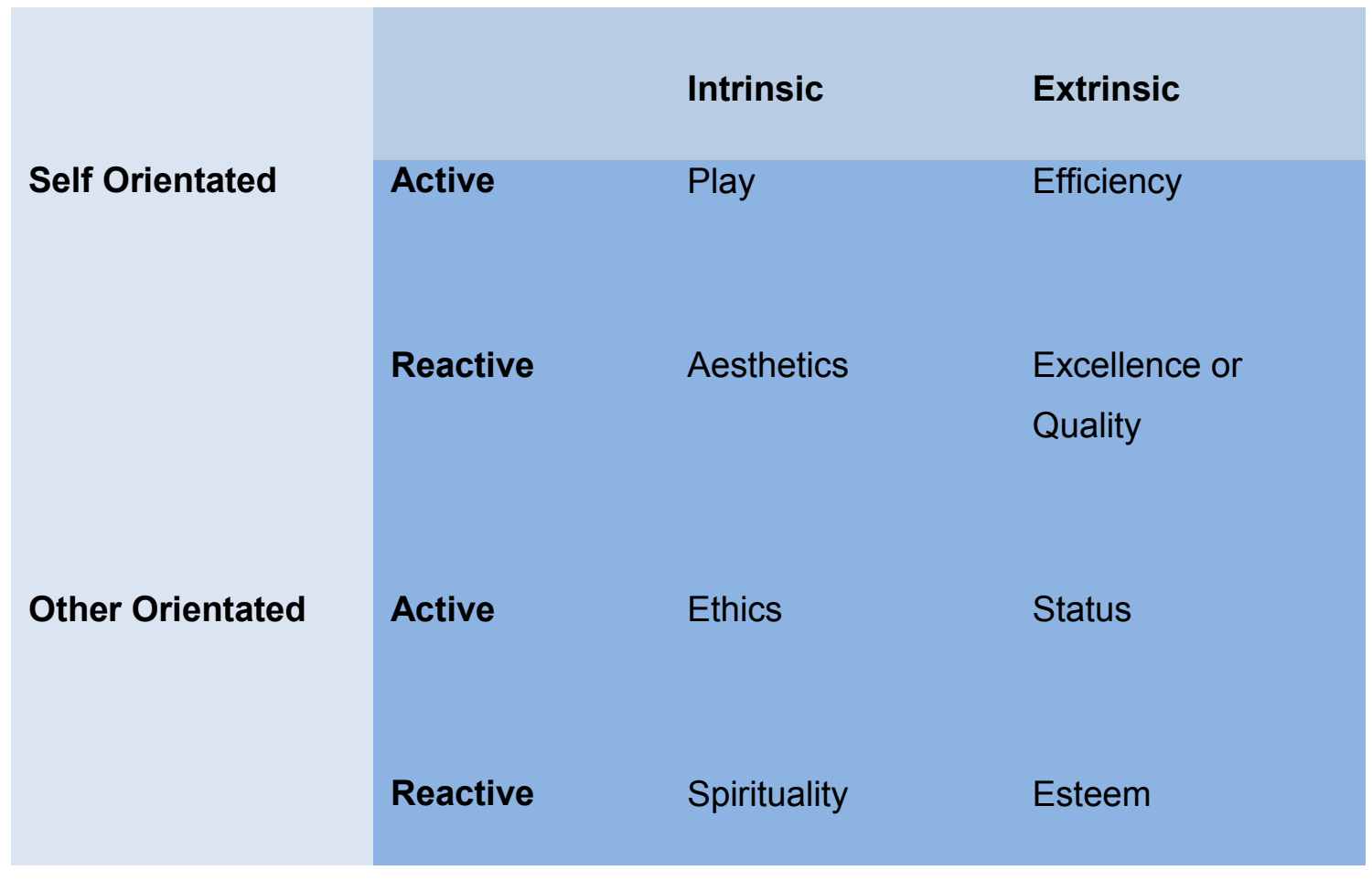

\section{Adapted from Holbrook (1999)}

None of this is meant to suggest that consumers will see value in behaviour choice as only one of the categories from the typology suggested by Holbrook. An event manager might, for example, recognise value in a personal sustainable choice from 'Status' as much as that described as 'Ethics'. One of the most difficult aspects is that there are self-oriented elements of value that suggest it is more convenient to act in a less sustainable manner. For example, to throw waste on the floor at an event may offer personally 'Efficiency' in comparison to carrying food containers about our person, or, to travel without car sharing may appear to be convenient but will not help the event achieve their sustainable goals.

This suggests that a key role for event management is to introduce circumstances that either encourage sustainable choices based on their basic values as discussed above, or, consider ways in which to add value for the consumer.

\section{A Framework for Developing Social Marketing Initiatives}

Table 2 captures the flow of the preceding consideration of literature and is intended to highlight a decision path for event managers seeking sustainable behaviour at their event.

Following adoption of a social marketing approach, the first step is in recognising the consumer target noted earlier as a self-selected audience for the event's main purpose. 
That's not to say that the event manager has no knowledge of the consumer as it would be expected that there is an overall target for the event defined by market segmentation factors (demographic, geographic, psychographic, behavioural, benefits sought). To recognise this gives an understanding of the consumer and, later, allows definition of appropriate social marketing initiatives.

\section{Table 2: The Decision Path for Social Marketing Initiative Development}

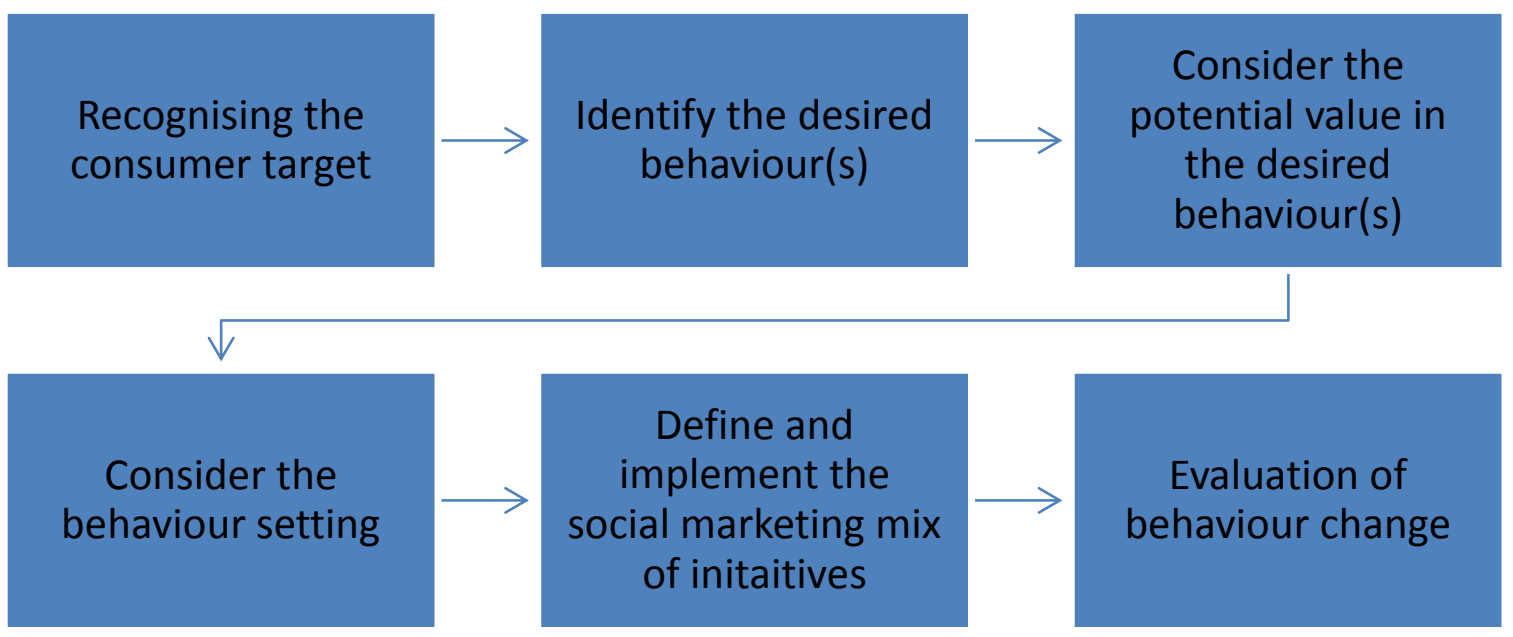

In a second step, the desired behaviours to achieve the sustainability objectives of the management need to be identified. As most sustainability objectives relate to the 'planet' elements of sustainable development, behaviours in general terms would aim to replace, reduce, reuse, recycle resources. However, specific and desired behaviours need to be identified in relation to the behaviour that is causing damage. In this social marketing context, the desired behaviour is the product itself and is far less open to alteration than typical commercial product or services. On the other hand, there may be a range of behaviours that are preferred to the one causing damage.

With desired behaviours identified, their consumer value should be considered in line with the types offered by Holbrook (1999) in order to be able to emphasise these within the social marketing initiatives. Noting that value in this sense may be seen as positive reward or negative punishment for choosing a specific behaviour and acts as the price element of the social marketing mix. Then, for events, it is essential to consider the behaviour setting earlier noted as offsite or onsite and as the place element of the social marketing mix. The social marketing mix for the initiative is completed by consideration of the promotion of this behaviour. Nowadays, this offers a variety of options to select ranging from traditional print media, social media or even games (Dieleman and Huisingh, 2006). Finally, the success of the initiative requires evaluation. 


\section{Discussion of Social Marketing Initiatives for Throwaway Tents}

By researching web content, a number of initiatives have been observed where festivals are attempting to reduce the waste due to throwaway tents. In Table 3, these are related to the framework developed earlier in order to consider whether this not only represents a good way to frame initiatives but also to develop other options. In adopting this approach to the analysis, the target consumer step discussion takes place within the consideration of initiative options as each festival will differ in this aspect.

Firstly, there are options to replace the use of a tent with a substitute which offers the same central benefit i.e. as accommodation. Green Outdoor (2013) provides an option to hire a tent for use for festivals which might suit those who wish to avoid storing tents at home. Potential value as a reward is the knowledge that this reduces waste (Ethics) and is a higher quality option (Excellence) but has punishment aspects in that the tent needs collecting and returning as well as being priced higher (Efficiency). Part of this punishment can be removed by having the tents available onsite at the festival provided by independent companies (Tangerine Fields, 2013; Pink Moon Camping, 2013) or the festival itself (Glastonbury, 2013). In these circumstances, the Excellence and Ethics values are achieved with only the high price as an Efficiency punishment. Michael Eavis is quoted (A Greener Festival, 2013) as saying, "I would actually like to see, in about 10-15 years time, a situation where every single tent is provided by us, and we can make sure that we can keep them, and store them for the following year." Whether such an ambition can be achieved will depend on demonstrating value to the consumer before the festival starts as the decision is made offsite. It is clear, therefore, that communication strategies require demonstration of the informational Ethics value and the utilitarian benefits of Excellence. This is true to an even greater extent looking at the final replacement behaviour option where the attendee uses the more luxurious accommodation of a motor vehicle such as a caravan. If this requires the attendee to hire or buy (rather than borrow), it would seem much more difficult to market this behaviour change as the potential punishment costs may appear to far outweigh the rewards. Whilst festival organisers may seek to increase the potential onsite rewards (with exclusive utilitarian elements such as access to hot water, etc like a holiday campsite) or, indeed, ban tents from the festival site altogether, this would appear to be an option that would only suit a target consumer with the disposable income that could support this behaviour choice. Not surprisingly, no evidence of such encouragement was found in the content analysis of tent and festival websites. 
Table 3: Initiatives to reduce waste from Throwaway Tents

\begin{tabular}{|c|c|c|c|c|c|c|c|}
\hline Aim & \multicolumn{7}{|c|}{ To reduce the tent waste at festivals by changing the behaviour of attendees } \\
\hline Basic Approach & \multicolumn{3}{|c|}{ Replace } & Reduce & Reuse & \multicolumn{2}{|c|}{ Recycle } \\
\hline $\begin{array}{l}\text { Behavioural } \\
\text { Strategy }\end{array}$ & \multicolumn{3}{|c|}{ To use an alternative resource that does not involve waste } & $\begin{array}{l}\text { To use less } \\
\text { resource }\end{array}$ & $\begin{array}{l}\text { To use the } \\
\text { resource } \\
\text { repeatedly }\end{array}$ & \multicolumn{2}{|c|}{$\begin{array}{c}\text { To convert the resource into another useful } \\
\text { resource }\end{array}$} \\
\hline Assumption & \multicolumn{3}{|c|}{ A less wasteful alternative resource exists } & $\begin{array}{l}\text { The undesirable } \\
\text { behaviour is an } \\
\text { inefficient use of } \\
\text { resource }\end{array}$ & $\begin{array}{l}\text { The resource can } \\
\text { be re-used and is } \\
\text { not unusable after } \\
\text { first use }\end{array}$ & \multicolumn{2}{|c|}{$\begin{array}{l}\text { The resource can be recycled into another } \\
\text { resource or used by another consumer }\end{array}$} \\
\hline $\begin{array}{l}\text { Potential } \\
\text { Behaviour } \\
\text { (Product) }\end{array}$ & $\begin{array}{l}\text { Hire of tent to take } \\
\text { to festival }\end{array}$ & $\begin{array}{l}\text { Hire of pre- } \\
\text { erected tents, etc } \\
\text { at the festival }\end{array}$ & $\begin{array}{l}\text { Use motor vehicle } \\
\text { i.e. caravan, } \\
\text { camper van, etc }\end{array}$ & $\begin{array}{l}\text { Encourage use of } \\
\text { smallest tent } \\
\text { does not make } \\
\text { sense on its own } \\
\text { without adopting } \\
\text { a further } \\
\text { behaviour }\end{array}$ & $\begin{array}{l}\text { Take tent home } \\
\text { after the festival } \\
\text { and use again }\end{array}$ & $\begin{array}{l}\text { Purchase of a } \\
\text { tent that can be } \\
\text { composted as } \\
\text { opposed to } \\
\text { added to landfill }\end{array}$ & $\begin{array}{l}\text { Leave tent for others to } \\
\text { recycle for same or } \\
\text { different use }\end{array}$ \\
\hline $\begin{array}{l}\text { Value (Price) Using } \\
\text { Holbrook Value } \\
\text { Types showing } \\
\text { Reward and } \\
\text { Punishment }\end{array}$ & $\begin{array}{l}\text { Reward: Ethics, } \\
\text { Excellence; } \\
\text { Punishment: } \\
\text { Efficiency }\end{array}$ & $\begin{array}{l}\text { Reward: Ethics, } \\
\text { Excellence; } \\
\text { Punishment: } \\
\text { Efficiency }\end{array}$ & $\begin{array}{l}\text { Reward: Ethics, } \\
\text { Excellence; } \\
\text { Punishment: } \\
\text { Efficiency }\end{array}$ & $\begin{array}{l}\text { Reward: Ethics; } \\
\text { Punishment: } \\
\text { None }\end{array}$ & $\begin{array}{l}\text { Reward: Ethics, } \\
\text { Efficiency, } \\
\text { Esteem, Status; } \\
\text { Punishment: } \\
\text { Efficiency }\end{array}$ & $\begin{array}{l}\text { Reward: Ethics; } \\
\text { Punishment: } \\
\text { Efficiency }\end{array}$ & N/A \\
\hline $\begin{array}{l}\text { Behaviour Setting } \\
\text { (Place) }\end{array}$ & Offsite & Offsite & Offsite & Offsite & Onsite & Offsite & Onsite \\
\hline $\begin{array}{l}\text { Marketing } \\
\text { Communication } \\
\text { (Promotion) }\end{array}$ & $\begin{array}{l}\text { Needs to } \\
\text { emphasise the } \\
\text { informational and } \\
\text { utilitarian value } \\
\text { versus the } \\
\text { increased } \\
\text { expenditure in } \\
\text { terms of time and } \\
\text { money }\end{array}$ & $\begin{array}{l}\text { Needs to } \\
\text { emphasise the } \\
\text { informational and } \\
\text { utilitarian value } \\
\text { versus the } \\
\text { increased } \\
\text { expenditure in } \\
\text { money terms }\end{array}$ & $\begin{array}{l}\text { Needs to } \\
\text { emphasise the } \\
\text { informational and } \\
\text { utilitarian value } \\
\text { versus the } \\
\text { potential much } \\
\text { increased } \\
\text { expenditure in } \\
\text { money terms }\end{array}$ & $\begin{array}{l}\text { Needs to } \\
\text { emphasise the } \\
\text { informational and } \\
\text { utilitarian value at } \\
\text { no added cost to } \\
\text { the attendee }\end{array}$ & $\begin{array}{l}\text { Needs to } \\
\text { emphasise the } \\
\text { informational and } \\
\text { utilitarian value } \\
\text { versus the } \\
\text { increased } \\
\text { expenditure in } \\
\text { terms of time and } \\
\text { effort }\end{array}$ & $\begin{array}{l}\text { Needs to } \\
\text { emphasise the } \\
\text { informational } \\
\text { value versus the } \\
\text { increased } \\
\text { expenditure in } \\
\text { terms of time and } \\
\text { money }\end{array}$ & N/A \\
\hline $\begin{array}{l}\text { Observed } \\
\text { Intervention }\end{array}$ & Green Outdoor & $\begin{array}{l}\text { Tangerine Fields; } \\
\text { Pink Moon } \\
\text { Camping; } \\
\text { Glastonbury }\end{array}$ & None & None & $\begin{array}{l}\text { Love Your Tent; } \\
\text { Re-Tent }\end{array}$ & $\begin{array}{l}\text { The Green Tent } \\
\text { Company }\end{array}$ & $\begin{array}{l}\text { V Festival/Rotary Club; } \\
\text { Upcycling; Esther } \\
\text { Porter; WiTHiNTENT; } \\
\text { Leeds } \\
\text { Festival/Everything is } \\
\text { Possible }\end{array}$ \\
\hline
\end{tabular}


The option to reduce the usage of tents is less obvious as a desirable behaviour. Attendees might use fewer tents (though many occupy one making this impossible) or use smaller tents (though the economics of purchase, carriage and storage suggest that few will have excess space). Furthermore, the main reduction of waste is only achieved if these attendees adopt a further behaviour as simply having a smaller tent and leaving this at the site has a negligible impact on the festival organiser's overall aim. Again, it's not surprising that no evidence of encouragement to behave in this way was found during the content analyse research. However, this behaviour could be encouraged as part of overall guidance to festival attendees.

The option to encourage festival attendees to take home their tent and reuse it later is commonly proposed with value in the Ethics sense as has been seen across all these behaviours. Efficiency in terms of the reward of reduced costs across a number of festival visits is contrasted with the punishment of packing up and carrying home a tent that might have suffered from poor weather or the abuse of its occupants. As this behaviour option doesn't require purchase of an alternative form of accommodation, its success hinges on the communication of value which seen as central in the Love Your Tent (2013a) campaign. Here, facts and figures were provided at the downstream level of the behaviour setting at the festival site where this informational value highlighted the damage caused by abandoning a tent. The utilisation of guidelines of behaviour and competitions (Love Your Tent, 2013b) to engage the festival goers assists in adding further value of Play as can be seen in the wording of the 'ten commandments' too. For example:

'Thou shalt be happy campers and share the love.'

Similarly, there was an effort "before the start of the festival season gathering support from festivals, social media sites and press, and campers" in a way that utilised upstream levels of social marketing as suggested by Andreasen (2006). Using recognised musicians as advocates helps to reinforce a largely informational value initiative by the use of even simple quotes such as this from Kelly Jones of Stereophonics:

\section{"Loveyourtent - pick up your $\mathrm{s}^{* *} \mathrm{t}$ - and leave!!"}

Similar efforts to add value to an initiative are seen in the work of Re-Tent (2013) who will spray the festival logo onto a tent which adds value by not only turning it into a souvenir (Esteem) but also a means to impress others at another festival (Status).

Turning to the initiatives for recycle, there are two basic choices to either compost the tent waste or to use it to allow others to use the tent or produce another product from the waste. 
However, these differ greatly in the behaviour expected of the consumer. An expectation to buy a compostable tent requires an increased cost with only Ethics value as reward though it appears that this has not proved a realistic option to date. The Green Tent Company has not produced a viable product in terms of being compostable and strong enough to meet consumer expectations (The Better Festival Group, 2010).

Many festivals have allowed the waste tents to be collected by others for use by charities (Rotary Club of Brewood and District, nd; The Northerner Blog, 2012), or sale (The Rotary Club of Kelvedon \& District, 2012), or to be turned into other products such as bags or clothing (Esther Porter, 2013; WiTHiNTENT, 2013). This latter process is, sometimes, termed as upcycling (Upcycling, 2013; The Boundary Sentinel, 2013). Such an initiative has the benefit for festival organisers that not only is waste reduced but clearance of the festival in a speedy manner can help meet agreements with the landowner. On a similar note, the You're Your Tent video (YouTube, 2013) shows one interviewee who recounts the convenient expectation of festival attendees that leaving your tent means someone else can use it. This point highlights the need to establish true informational value when implementing initiatives. Finally, no evaluation of the true recycling of materials was discovered by the research which indicates the importance of the last step of the framework.

\section{Conclusions and Recommendations}

The overall aim of this conceptual paper was to develop a framework for strategic decision making to address behavioural change and achieve sustainable objectives at festivals. In Table 2, the step by step process has been summarised and applied at an introductory level to the throwaway tent problem at festivals in Table 3. The following conclusions and recommendations have been reached.

Whilst the examination of the framework was done by using one particular issue for festivals per-se as opposed to consideration how that issue impacts a specific festival and its audience, the synthesising of social marketing, behavioural elements and consumer value appear to have provided a mechanism that can help management determine the behaviour options as initiatives that might best be presented to their audience and how that might be done.

Secondly, it can be seen from the initiatives adopted for a problematic, low involvement behaviour decision (Rothschild, 1979) that the chances of success appear to be increased by the consideration of means to add in value at the downstream social marketing level. Whilst arguably this is an obvious conclusion, little examination of such an approach has been done to date. 
Thirdly, the relevance of the offsite/onsite behaviour setting varies between the initiatives in terms of where the consumer is influenced though upstream and downstream elements to the initiatives have been observed as suggested by Andreasen (2006).

Finally, little has been found to reflect the final evaluation step of the framework whilst its importance is obvious. At an introductory level this paper has been useful to reflect upon the application of the conceptual framework to festival websites. Yet a thorough analysis that follows the aforementioned methodology would enable a systematic situational analysis of social marketing practices used at major UK festivals that aim at altering behaviour. This would also allow for in-depth field work and enable the authors to include an 'evaluation of success' in future research.

Clearly, this research is exploratory in its development of a framework for strategic decision making in areas requiring behaviour change in a sustainable direction. Future study would reflect application of such strategies in terms of the practicalities of this framework and its success in terms of achieving sustainable event goals.

\section{References}

A Greener Festival (2013) Glastonbury Flags Up Left Behind Tents.

Available at http://www.agreenerfestival.com/2013/02/glastonbury-flags-up-dumped-tentsissue/ (Accessed 30 May 2013).

Allan, J. (2010) Personal communication to Stephen Henderson on 1 October 2010.

Amaya, M., \& Petosa, R. L. (2012). An evaluation of a worksite exercise intervention using the social cognitive theory a pilot study. Health Education Journal, 71(2), pp 133-143.

Andreasen A.R. (2006) Social Marketing in The $21^{\text {st }}$ Century. Thousand Oaks, California, Sage.

Bandura, A. (2002) "Social Cognitive Theory in a Social Context", Applied Psychology: An International Review, 51/2, pp 269-290.

Church, M.J. (2012), Advantages of Event Waste Management. Available at: http://www.event-waste-management.com/advantages-event-waste-management (Accessed 17 April 2013). 
Cierjacksa, A., Behrb, F. and Kowarika, I. (2012), Operational performance indicators for litter management at festivals in semi-natural landscapes, Ecological Indicators, Volume 13, Issue 1, pp 328-337.

Cramp, A. G., and Brawley, L. R. (2006). Moms in motion: A group-mediated cognitivebehavioral physical activity intervention. International Journal of Behavioral Nutrition and Physical Activity, 3(1). Available at: http://www.ncbi.nlm.nih.gov/pmc/articles/PMC1564034/, (Accessed 13 April 2013).

Dieleman, D. and Huisingh, D. (2006) Games by which to learn and teach about sustainable development: exploring the relevance of games and experiential learning for sustainability. Journal of Cleaner Production, 14, pp 837-847.

EEA (European Environment Agency) (2012) Waste and Material Resources. Available at: http://www.eea.europa.eu, (Accessed 13 April, 2013).

Esther Porter (2013) About. Available at http://www.estherporter.co.uk/about (Accessed 30 May 2013).

Frame, B. and Newton, B. (2007), Promoting sustainability through social marketing:

Examples from New Zealand, International Journal of Consumer Studies, 31, 6, pp 571-581.

Foxall, G.R. (1999) The Behavioural Perspective Model: Consensibility and Consensuality, European Journal of Marketing, 33 (5/6), pp 570-596.

Glastonbury Festival (2013) Worthy View's Scout-Style Tents.

Available at http://www.glastonburyfestivals.co.uk/news/worthy-views-scout-style-tents (Accessed 30 May 2013).

Green Outdoor (2013) Tent Hire.

Available at http://www.greenoutdoor.co.uk/rent-a-tent (Accessed 30 May 2013).

Gordon, R. (2011). Critical Social Marketing: definition, application and domain. Journal of Social Marketing, 1, 2, pp 82-99.

Haq, G., Whitelegg, J., Cinderby, S. and Owen A. (2008) The use of personalised social marketing to foster voluntary behavioural change for sustainable travel and lifestyles, Local Environment, 13, 7, pp 549-569. 
Holbrook, M. B. (1999). Introduction to Consumer Value In: Holbrook, Morris B. ed Consumer Value: A framework for analysis and research, Routledge, London and New York.

Jones, B., Scott, D. and Abi Khaled, H. (2006) Implications of climate change for outdoor event planning: a case study of three special events in Canada's national capital region. Event Management, 10, pp 63-76

Kurani, K., \& Turrentine, T. (2002). Marketing Clean and Efficient Vehicles: A Review of Social Marketing and Social Science Approaches. University of California: Institute of Transportation Studies.

Kotler, P., Armstrong, G., Wong, V. and Saunders, J. (2008) Principles of Marketing Fifth European Edition. Prentice Hall, Harlow, UK.

Kotler P. and Lee N. (2008), Social Marketing: Influencing behaviours for Good, 3rd edition, Sage, Thousand Oaks, California.

Herring, S. C. (2010). Web content analysis: Expanding the paradigm. In International handbook of Internet research (pp 233-249). Springer, Netherlands.

Henderson, S. (2011), The Development of Competitive Advantage through Sustainable Event Management, Worldwide Hospitality and Tourism Themes. Vol. 3, Issue 3, pp 245257.

Henderson, S. (2013), Sustainable Touring: Exploring Value Creation through Social Marketing, Arts Marketing: An International Journal. Vol. 3, Issue 2, pp.154 - 167.

Lin, C. P. (2010). Learning virtual community loyalty behaviour from a perspective of social cognitive theory. Intl. Journal of Human-Computer Interaction, 26(4), pp 345-360.

Love Your Tent (2013a) The Campaign. Available at http://loveyourtent.com/section.php?s=3 (Accessed 30 May 2013).

Love Your Tent (2013b) The Tent Commandments. Available at http://loveyourtent.com/subsection.php?s=3\&ss=6 (Accessed 30 May 2013).

McKenzie-Mohr, D. (2000) 'Promoting Sustainable Behaviour: An Introduction to Community-Based Social Marketing', Journal of Social Issues, 56, 3, pp 543-554. 
Mair, J. and Laing, J. (2013): Encouraging pro-environmental behaviour: the role of sustainability-focused events, Journal of Sustainable Tourism, pp 1-13, available at http://www.tandfonline.com/doi/full/10.1080/09669582.2012.756494 (Accessed 13 November 2013).

Mintel (2012) Music Concerts and Festivals UK - August 2012 [online]. Available at http://oxygen.mintel.com/sinatra/oxygen/list/id=590295\&type=RCltem\#0 1 page RCltem =0, (Accessed 12 February 2013].

Mullins, L. J. (2007) Management and Organisational Behaviour. Financial Times/Prentice Hall.

O'Connor, R. E., Bord, R. J., Yarnal, B., and Wiefek, N. (2002). Who wants to reduce Greenhouse Gas Emissions? Social Science Quarterly, 83(1), pp 1-17.

Peattie, K. and Peattie, S. (2009) 'Social marketing: A pathway to consumption reduction?' Journal of Business Research, 60, 2, pp 260-268.

Pink Moon Camping (2013) A Unique Camping Experience.

Available at http://www.pinkmooncamping.co.uk/ (Accessed 30 May 2013).

Re-Tent (2013) Encouraging Tent Re-Use Amongst Festival Goers.

Available at http://www.retent.co.uk/ (Accessed 30 May 2013).

Rotary Club of Brewood and District (nd) V-Festival Tent Collection. Available at http://www.brewood-rotary.co.uk/tents.htm (Accessed 30 May 2013).

The Rotary Club of Kelvedon \& District (2012) Rotary aiming to clean up in second-hand tent market. Available at http://www.thisistotalessex.co.uk/Rotary-aiming-clean-second-handtent-market/story-16719212-detail/story.htm|\#axzz2UnPXPcQj (Accessed 30 May 2013).

Rothschild, M. (1999) Carrots, Sticks, and Promises: A conceptual framework for the management of public health and social issues behaviour, Journal of Marketing, 63, 10, pp 24-37.

Rothschild, M. (1979) Marketing communications in nonbusiness situations or why it's hard to sell brotherhood like soap. Journal of Marketing, Vol. 43, No 2, pp 11-20. 
Salhofer S.P., Obersteiner G., Schneider F., Lebersorger S. (2008). Potentials for the Prevention of Municipal Solid Waste. Waste Management, Vol. 28, No. 2, pp 245-259.

Santos, I.R., Friedrich, A.C., Wallner-Kersanach, M., Fillmann, G., (2005). Influence of socioeconomic characteristics of beach users on litter generation. Ocean \& Coastal Management. Volume 48, Issues 9-10, pp 742-752.

Shaw, D., Grehan, E., Shiu, E., Hassan, L. and Thomson, J. (2005). An exploration of values in ethical consumer decision making. Journal of Consumer Behaviour, 4, 3, pp 185-200.

Shirley, M. D. F., Armitage, V. L., Barden, T. L., Gough, M., Lurz, P. W. W., Oatway, D. E., ... \& Rushton, S. P. (2001). Assessing the impact of a music festival on the emergence behaviour of a breeding colony of Daubenton's bats (Myotis daubentonii). Journal of Zoology, 254, 3, pp 367-373.

Smithers, R. and Ladmore, S. (2011) Thousands of 'festival' tents destined for landfill. Available at http://www.guardian.co.uk/environment/2011/jul/07/festival-tents-landfill/ (Accessed 30 May 2013).

Solomon, M.R., Bamossy, G.J., Askegaard, S., Hogg, M.K., (2010) Consumer Behaviour: A European Perspective. $4^{\text {th }}$ Edition. Harlow, England, Prentice Hall.

Silva-Cavalcanti, J. S., de Araújo, M. C. B., and da Costa, M. F. (2009). Plastic litter on an urban beach-A Case Study in Brazil. Waste Management \& Research, 27(1), pp 93-97.

Tangerine Fields (2013) Camping Made Simple.

Available at http://www.tangerinefields.co.uk/events.html/ (Accessed 30 May 2013).

The Better Festival Group (2010) Green Tent Company.

Available at http://www.thebetterfestivalgroup.co.uk/links/green-tent-company (Accessed 30 May 2013).

The Boundary Sentinel (2013) After the Party: Upcycling the Detritus from Shambhala Music Festival. Available at http://boundarysentinel.com/news/after-party-upcycling-detritusshambhala-music-festival-23853\#.UWB8mMu9KSM (Accessed 30 May 2013).

The Northerner Blog (2012) Hundreds of tents abandoned at Leeds Festival will be scavenged for those in need. Available at http://www.guardian.co.uk/uk/the- 
northerner/2012/aug/20/leeds-festical-recycling-camping-gear-everything-is-possuble (Accessed 30 May 2013).

Tonglet, M., Phillips, P. S., \& Read, A. D. (2004). Using the Theory of Planned Behaviour to investigate the determinants of recycling behaviour: a case study from Brixworth, UK.

Resources, Conservation and Recycling, 41, 3, pp 191-214.

WiTHiNTENT (2013) Welcome to WiTHiNTENT. Available at http://www. withintent.co.uk/ (Accessed 30 May 2013).

YouTube (2013) Love Your Tent - A Greener Festival Film. Available at http://www.youtube.com/watch?v=Px6qfsRXv2w (Accessed 30 May 2013).

Zaichkowsky, J. L. (1986). Conceptualizing Involvement. Journal of Advertising, 15, Issue 2, pp 4-14. 